\title{
PLANNED AND RATIONAL MANAGEMENT OF THE BROWN HARE (LEPUS EUROPAEUS PALLAS,1778) POPULATION IN VOJVODINA REGION (SERBIA) FOR THE PAST 50 YEARS (1967-2016)
}

\author{
Zoran A. Ristić ${ }^{1}$, Miroslav I. Urošević ${ }^{2}$, Nemanja Ristić ${ }^{3}$, Milosava Matejević ${ }^{1}$, Igor Ponjiger ${ }^{1}$, \\ Milutin Kovačević ${ }^{1}$, Predrag Ćirović ${ }^{4}$, Aleksandra Prodanović ${ }^{1}$
}

Summary: Research on the percentage of young in the brown hare (Lepus europaeus Pall.) population in Vojvodina has been carried out since 1967 until 2016. The number of hare in this period ranged from minimum 154,990 individuals (with an average density of the population of 8.06) in 2014 to a maximum recorded in 1975 with 301,680 individuals (with an average population density of 15.10). An average number of hares recorded during annual spring counts was 265,070 with an average population density of 13.15 individuals per 100 ha. The average annual recorded cull was 40,495 hares (15.28\% of spring hare count). For this period, each year in the Laboratory for Hunting, tests were carried out on hare (eye lens), and all hunting clubs were obliged to deliver samples in order to be given permission to hunt. In total, there were 9,648 samples, which on average for the 49-year research period amounted to 197 per year.

The largest number of samples was in 2009, when 300 hunting clubs, or two-thirds, delivered eye lenses to the laboratory for analysis. For the 1967-2016 period an average of 7,967 hare eye lenses (years 1971 and 1972 must be excluded with 605 and 587 eye lenses when a total hunting ban was made, and only hunting was carried out for scientific research). The average share of young for the observed period was $57.6 \%$, with the minimum recorded in 2014 of $35.9 \%$ and a maximum of $70.3 \%$ in 1994 . The reproductive index ranged from 1.09 to 2.33 hare per female in 1994.

The results of our research showed the diversity of selected population dynamics indicators for all hunting grounds in Vojvodina that were compared with similar research in Europe. Hunting, as shown, doesn't jeopardize the population, but other factors such as intensive soil cultivation with large agricultural plots and excessive use of pesticides followed by improper use.

Keywords: brown hare, eye lens, real growth

\section{Introduction}

Agricultural land is considered to be the primary habitat of the brown hare, Lepus europaeus Pallas, 1778, across Europe (Meriggi \& Alieri, 1989; Harris et al., 1995; Marboutin \& Aebischer, 1996). Brown hare is one of many species that can be affected by habitat changes caused by an intensification of agriculture (Tapper \& Parsons, 1984; Slamečka, 1991; McLaren et al., 1997). A review of the data on the number of brown hare in European countries suggests that populations have dropped throughout Europe, especially since the 1960s (Pielovski \& Pucek, 1976; Tapper \& Parsons, 1984; Mitchell-Jones et al., 1999). As a result, the brown hare is protected in Annex III of the Convention on the Conservation of European Wildlife and Natural Habitats (Bern Convention, Anonymous 1979). Other explanations for declining of brown hare include an increase in the population of predators (Tapper \& Barnes, 1986; Panek \& Kamieniarz, 1999) and climate change such as, for example, precipitation increase (Hacklander et al., 2002). The effects of changes in habitat, predators, and climate, individually or collectively, affect the populations of the brown hare.

\footnotetext{
${ }^{1}$ Zoran A. Ristić, PhD, Full Professor; Milosava Matejević, PhD, Assistant Professor; Igor Ponjiger, PhD, Assistant: Milutin Kovačević, PhD, Assistant Professor; Aleksandra Prodanović PhD, Department of Geography, Tourism and Hotel Management, Faculty of sciences, University of Novi Sad, Trg D. Obradovića 3, Novi Sad

Nemanja Ristić, BSc. student, Department of Biology and Ecology, Faculty of Sciences, University of Novi Sad, Trg D. Obradovica 3, 21000 Novi Sad, Serbia

${ }^{3}$ Miroslav I. Urošević, PhD, Assistant Professor, Assistant professor, Dep. of Animal science, Faculty of Agriculture, University of Novi Sad, Trg D. Obradovića 8, Novi Sad

${ }^{3}$ Predrag Ćirović, MSc., Adviser, Forest Directorate, Ministery of Agriculture, Forestry and Water Management of Serbia, Omladinskih Brigada 1, New Belgrade

Corresponding author: Miroslav I. Urošević, miroslav.urosevic@stocarstvo.edu.rs
} 
Brown hare is common in arable landscapes and less common in untreated areas such as pastures, elevations and forest lands (Tapper \& Parsons, 1984; Hutchings \& Harris, 1996; Klansek et al., 1998; Vaughan et al., 2003). Jovanović and Aleksić (1976) studied the human influence on the population of brown hare, and before that, in 1971 and 1972, when the hare population was so reduced that hunting was prohibited throughout Vojvodina in order to recover the population. The lowest density was recorded in 1971, of only 9.60 hare per 100 ha, and this is repeated in 2014 after 43 years when an absolute minimum of 8.06 is recorded, only one year later (2015), the density almost equaled from 1971 with 9.96. Figure 1. shows the population dynamics for the entire observed period.

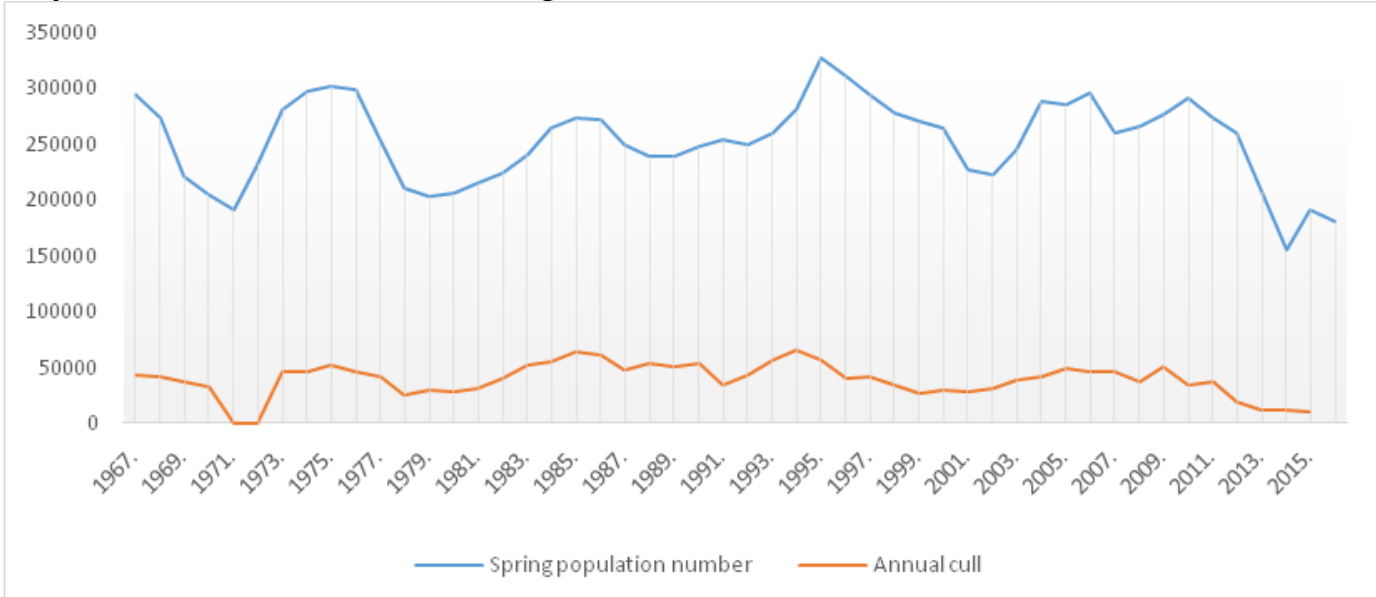

Figure 1. The spring population number and annual cull in Vojvodina region during the 1967-2016 period

Further research in Yugoslavia (Vojvodina) showed that the average survival rate for young hares until hunting season in the period of 10 years (1967-1976) was 23.3\% (Jovanović et al., 1971; Šelmić, 1977). Such a negative population trend has also been recorded in other European countries, as described by Hell and Panek with associates (Hell et al., 1997; Panek \& Kamieniarz, 1999), which explain the reduction of the population by exacerbating life opportunities within such ecosystems. The reduction in the density of the brown hare population in the territory of Croatia, for the last forty years, was described by Car (1973) and Alegro (1981). In addition to biotic (increased number of predators, in particular foxes and jackals) and abiotic (worsening climatic conditions in hunting areas that adversely affect the population, such as high precipitation from April to June, after which large droughts) that affect the brown hare population, human impact is very important and can cause severe damage to hare populations, especially when it comes to their over-exploitation (Kolar, 2003; Šelmić, 1984).

In order of achieving rational and planned management of the hare population, when the ecological conditions deteriorate, constant monitoring of populations is necessary through certain population parameters. This can be done by annual counting during the spring after the end of winter losses, determining the density of the population for that year and comparing it with data from the hunting management plan, comparing data with the percentage of young from previous years and real growth.

Based on such indicators, it is necessary to annually plan the structure, method and period of exploitation of the observed hare population (Šelmić, 1984). Also, losses in the period of reproduction and winter losses need to be taken into account, that was investigated by Ristić and Matejević (2010). The results of previous studies on the number of losses in the period of reproduction and winter losses are very different in Vojvodina and in the neighboring countries. 


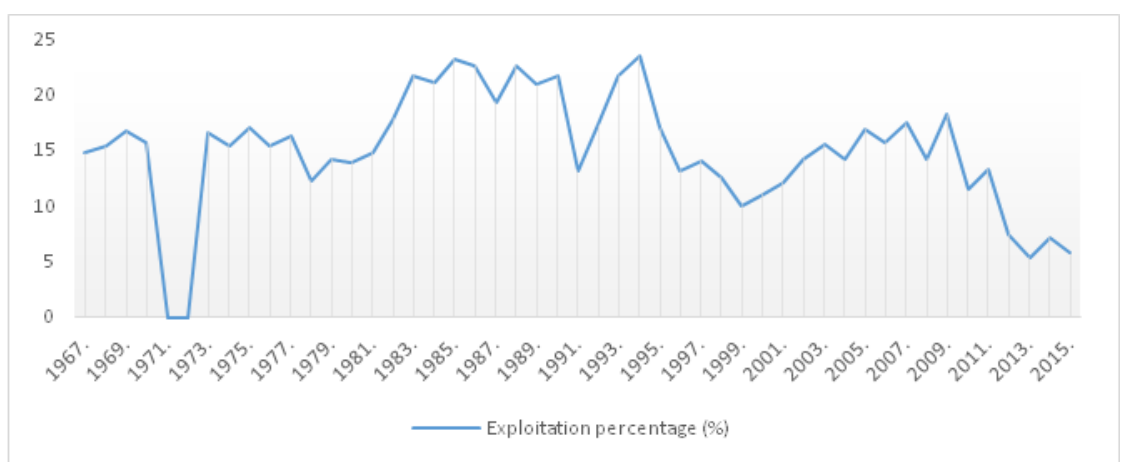

Figure 2. Percentage of brown hare population exploitation for the 1967-2016 period

For the period of 42 years, on the basis of the same research, the losses in the period of brown hare reproduction ranged from 11.93 to $47.01 \%$, or an average of $32 \%$ per year. Data on double losses are necessary for the development of realistic planning documents (annual hunting management plans). Exploitation or cull, in the observed period of 1967-2016, recorded maximum in 1994 with $65,848-23.50 \%$ hares (Figure 2.). The minimum recorded cull was in 2015 with 11,010 hares (Figure 3.).

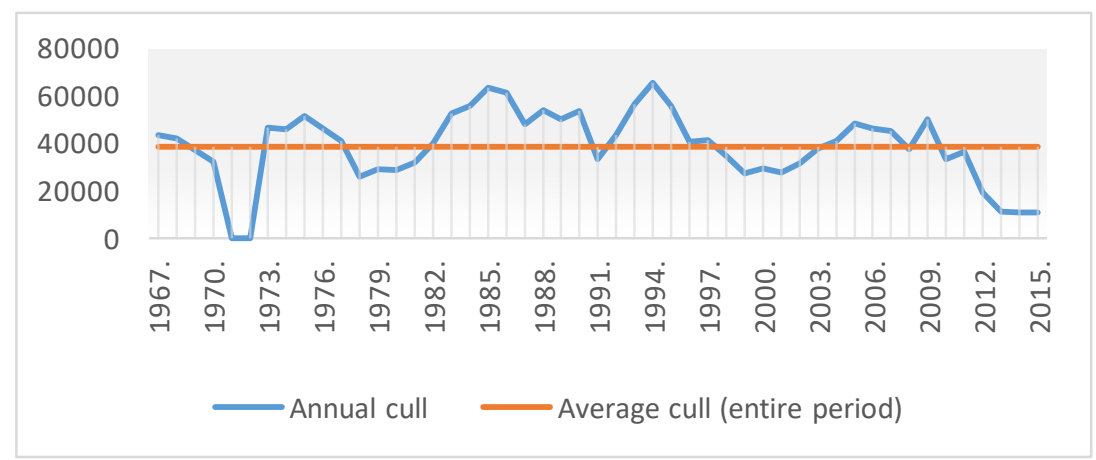

Figure 3. Annual brown hare cull and average cull calculated for the entire research period

Aim of this paper is colecting all available data on brown hare population and hunting. Based on that data goal is to determine the real growth of the brown hare population in the Vojvodina region - Serbia.

\section{Material and methods}

Planned management of the brown hare population in Vojvodina began in 1967 when the research started with the Hunting Laboratory of the Faculty of Agriculture in Novi Sad, with the support of the Hunting Association of Vojvodina. The sampling method consisted in the fact that one of the eyeballs was removed from the hunted hares during the first hunt in the season, and then processed further in the laboratory.

For the period of 1967-2016, a total of 390,380 eye lenses were sampled from the same number of brown hares in the Hunting Laboratory or an average of 7,967 per year. The average percentage of samples taken for this period is $3.13 \%$. Eye samples were always taken from the first two hunting days on brown hare hunting season. The hunting season took place from October 15 to December 31, until the nineties when hunting season began November 1st until December 31st.

After collecting, eye lenses were processed in the Hunting Laboratory of the Faculty of Agriculture in Novi Sad, and since 1987 in the Hunting Association of Vojvodina. They were placed for three days in a 10\% formalin mixture and then dried in a thermostat at $55-60^{\circ} \mathrm{C}$ for a total of 72 hours - three days. After the drying was completed, the mass was measured on a precision scale (Metler) at $5 \mathrm{mg}$ accuracy. The applied method proved to be sufficiently reliable for estimating the age of juveniles (up to 9-10 months old) and can be applied with great precision to distinguish juvenile hares up to 1 year old from adults older than a year (Šelmić, 1984.; Suchentrunk et al., 1991).

Based on the weight in the dry state of the glass part of the eye lens, brown hare populations are categorized into six age groups (Table 1.). 
Table 1. Mass of the hare eye lens and appropriate age

\begin{tabular}{|c|c|c|}
\hline Age class & Mass of the eye lens in mg & Estimated age \\
\hline I & $<100 \mathrm{mg}$ & less than 3 months \\
\hline II & $100-200 \mathrm{mg}$ & 3 to 6 months \\
\hline III & $200-280 \mathrm{mg}$ & 6 to 12 months \\
\hline IV & $280-310 \mathrm{mg}$ & 1 to 2 years \\
\hline V & $310-370 \mathrm{mg}$ & 3 to 4 years \\
\hline VI & $370<\mathrm{mg}$ & older than 4 years \\
\hline
\end{tabular}

Source: Šelmić, 1984

Values between age classes were determined on the basis of research by Andersen and Jensen (1972) and criteria by Möller (1975) and Šelmić (1977). Border value of the mass of the eye lens between juvenile and adult hare was $280 \mathrm{mg}$, based on previously established studies by Šelmić (1984) and Slamečka and associates (1997).

Based on the obtained parameters of eye lens measurements from population indicators during this study, the share of young hares in the cull, the reproduction coefficient, the reproduction index, and the real growth were determined. The spring population number of hares in Vojvodina was carried out on 10-12\% of hunting-productive areas for brown hare in hunting grounds in Vojvodina, calculated as an average number of individuals per 100 ha (Šelmić, 1984; Slamečka et al., 1997).

The obtained results were analyzed using the SAS GLM Procedure (1999). The attached formulas are used to calculate individual indicators:
1. Reproduction coefficient
$\mathrm{N} j u v$$$
\mathbf{r}=------
$$
2. Reproduction index

$$
\mathbf{R}=\frac{\mathrm{N} j u v}{\mathrm{~N} a d}
$$
3. Real growth
$\mathbf{R G}=\frac{j u v-30}{-100-j u v}$

$\mathrm{N} j u v$-number of young hares; Nad-number of adult hares; Nadf-number of adult females

RGC - real growth coefficient

$$
\mathbf{R G C}=0 \begin{gathered}
\mathrm{N} j u v \\
\mathrm{~N} A d
\end{gathered}
$$

\section{Results}

The results of the analysis based on the obtained population indicators for the investigated period (19672016) are: the reproduction coefficient $(\mathrm{R})$ for all hunting grounds in Vojvodina was 1.36; the reproduction index (r) is 2.72; real growth (RG) of $65.09 \%$ and real growth coefficient (RGC) of 1.65 (Figure 4.). 


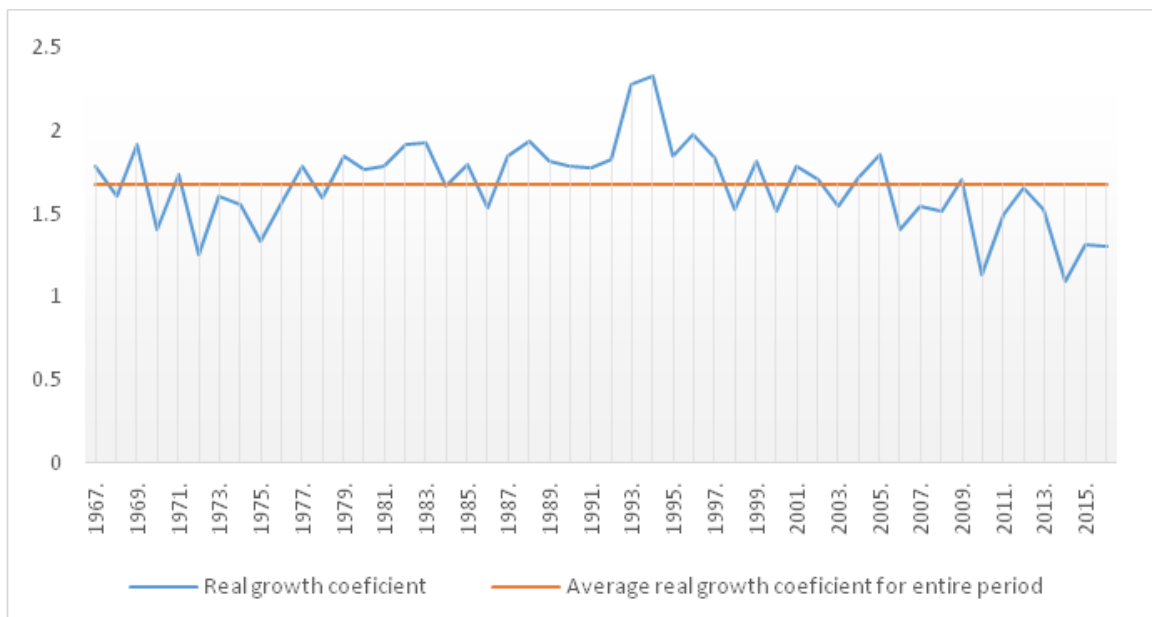

Figure 4. Real growth coefficient of brown hare population in Vojvodina region for the 1967-2016 period

Determination of real growth is based on the share of young individuals in the cull. When the share was over $60 \%$ it was considered good - excellent, $50-60 \%$ is considered medium good and less than $50 \%$ is considered weak (Slamečka et al., 1997). Figure 5. shows the share of young hares in entire population for the Vojvodina region.

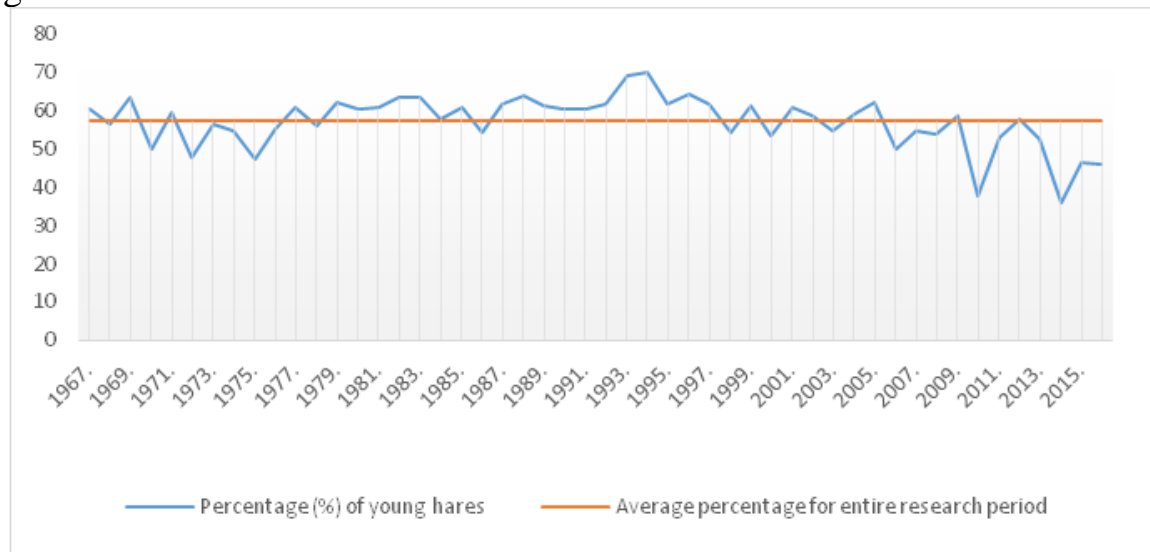

Figure 5. Percentage (\%) of young hares in the population in Vojvodina region for the 1967-2016 period

\section{Discussion}

A similar variation in the share of young hares was also determined for the territory of Croatia (38-60.7\%) (Pintur et al., 2006; Popović et al., 2008). Such variations vary from year to year, as also stated by other authors (Ahrens, 1996; Slamečka et al., 1997; Šelmić et al., 1999; Kolar, 2003; Marboutin et al., 2003). Pintur et al. (2006) study show that the average share of hares younger than one year was $50.4 \%$ of the total population. The breeding index, as an indicator of the survival rate of young hares per female, significantly jumped from 1.33 to 3.40 . The average value of the breeding coefficient was 1.07. Popović et al. (2008) found for the hunted areas surveyed, the average share of young individuals was $46.7 \%$ of the total brown hare population. The reproduction index varied from 0.62 to 3.40 , and the reproduction coefficient ranged from 0.62 to 1.54 . Analysis of data from hunting management plans for the last 40 years has shown that the cull was reduced by 9 times, and the number of population in 2005, compared to 1967, was reduced by $56 \%$. By analyzing the size of the hunting-productive area from the hunting management plans it was found that its decrease in the mentioned period was $62 \%$, which is probably the main reason for the current trend of declining population numbers in Medjimurje (Popović et al., 2008). Such high heterogeneity of the achieved growth was also described by Šelmić et al. (1999) for the area of Vojvodina in the period from 1973 to 1998. The values of the reproduction coefficient $(\mathrm{R})$ and reproduction index $(\mathrm{r})$, as an indicator of reproduction success, varied considerably during the observed years. Similar values of this index were determined by 
Semizorova and Schwartz (1987) in the Czech Republic and Slamečka et al. (1997) in Slovakia (1.0-2.0). The causes of these differences in the survival of young hares per female (r) between continental and Mediterranean habitats can be sought in a range of abiotic and biotic factors such as climatic conditions, increased predator pressure over the past ten years, the negative impact of human activities with increased and improper use chemicals in agriculture. The real causes of such events should be investigated in each case (Šelmić, 1984; Slamečka et al. 1997). The results of the research for a long period such as 1967-2016 showed the diversity of selected population dynamics indicators for all hunting grounds in Vojvodina that were compared with similar research in Europe. Some authors define winter losses only as direct losses, from the impact of winter and snow, and the consequence is the lack of food due to the depth of the snow cover. Others count on the overall losses in the population but do not define the period to which they relate, and don't count on losses that occur during the hunting season. Only Erdeš (1978) and Ladžinski (1977) paid attention to these losses.

According to the research of Ristić and Matejević (2010), the average losses from the beginning of hunting season (October) until the beginning of the next reproduction period (March) range from $12.58 \%$ to $45.47 \%$, or $32 \%$ annually for a period of 41 years in Vojvodina.

The planned management of the brown hare population for all hunting grounds in Vojvodina, due to large areas, plots, under monocultures as a specific ecosystem, requires great efforts to preserve the population, which is becoming increasingly vulnerable. Hunting, as shown, doesn't jeopardize the population, but other factors such as intensive soil cultivation with large agricultural plots and excessive use of pesticides followed by improper use. Also, due to global climate changes the phenomenon of extremely low and extremely high temperatures with the lack of food and water is common, with an increased number of feathered predators such as magpies and gray crows, but also of other species. Other predators also affect the population (Marboutin et al. 2003). The number of foxes rose since 2010 when the vaccination against rabies has been carried out. Number of jackals is on the rise along with the constant presence of species like European pine marten, beech marten, badger (Ristić et al. 2016).

\section{Conclusion}

Population of brown hare in Vojvodina faces serious challenges under constantly changing habitat conditions. One of the ways for preservation of this population is constant monitoring and planned management. As shown hunting does not jeopardize the population when done sustainably and according to the management plans. Problems caused by intensive agriculture, climate change and abundance of predators need to be taken into account by the experts. The only rational solution is to monitor all these parameters annually and based on that make plans and realize cull in a sustainable way. This way a long term population plans can be done which will in return preserve the population.

\section{Acknowledgement}

The presented work is part of the research done in scientific project „TR-31084“ and „III-46005“ granted by the Serbian Ministry of Education and Science.

\section{REFERENCES}

1. Anonymous (1979) Convention on the conservation of European wildlife and natural habitats. Council of Europe, Strasbourg. https://rm.coe.int/1680078aff

2. Anonymous (1979) Convention on the conservation of European wildlife and natural habitats. Bern Convention. Council of Europe, Strasbourg.

3. Alegro, A. (1981) Zaštita zeca. Lovački vjesnik 90 (6), pp. 137-139.

4. Ahrens, M. (1996) Untersuchungen zu Einflußfaktoren auf die Besatzentwicklung bei Feldhasen in verschiedenen Gebieten Sachsen-Anhalts. Beitr. Jagd- und Wildf. 21, pp. 229-235.

5. Andersen, J., Jensen, B. (1972) The weight of the eye lens in the European hares of known age. Acta Theriologica, 17 (1-11) pp. 87-92.

6. Car, Z.(1973) O zecu odgovorno, a prije svega stručno. Lovački vjesnik 82(3), pp. 65-68. 
7. Hackländer, K., Arnold, W., Ruf, T. (2002) Postnatal development and thermoregulation in the precocial European hare (Lepus europaeus). Journal of Comparative Physiology B, 172, pp. 183190.

8. Harris, S., Morris, P., Wray, S. \& Yalden, D. (Eds.). (1995). A Review of British Mammals: Population Estimates and Conservation Status of British Mammals other than Cetaceans. Peterborough, UK: Joint Nature Conservation Committee.

9. Hutchings, M.R. \& Harris, S. (Eds.). (1996). The Current Status of the Brown Hare (Lepus europaeus) in Britain. Peterborough, UK: Joint Nature Conservation Committee.

10.Jovanović, V., Kostić, P., Aleksić, D. (1971) Prilog proučavanju godišnjeg priraštaja zečeva u Vojvodini i uticaj meteoroloških faktora na prirast, Simpozijum o lovstvu, Beograd.

11.Jovanović, V, Aleksić, D (1976) Prilog proučavanju meteoroloških elemenata na realan godišnji priraštaj zeca u Vojvodini, Simpozijum o lovstvu, Beograd, Zbornik radova, pp. 291-297.

12.Kolar, B. (2003) Većina uplenjenih zajcev je bila starejših od 2 let. Lovec 11, pp. 519-521.

13.Klansek, E., Kalivodová, E., Šimonovič, V. Kürthy, A. (1998) Landscape-ecological evaluation of the flood plain of the River March (Morava) with regard to hare (Lepus europaeus Pallas) and roe deer (Capreolus capreolus L.). Ekológia (Bratislava), 17, pp. 201-207.

14.Pintur, K., Popović, N., Alegro, A., Severin, K., Slavica, A., Kolić, E. (2006) Selected indicators of brown hare (Lepus europaeus Pallas, 1778) population dynamics in northwestern Croatia, Vet. arhiv 76 (Suppl.), pp. 199-209.

15.Ladzinsky A. (1977) Perspektivna produkcija jednotlivych polovnej zveri v SSR, Folia venatoria, 7, Bratislava.

16. Marboutin, E., Aebischer, N.J. (1996) Does harvesting arable crops influence the behaviour of the European hare Lepus europaeus? Wildlife Biology, 2, pp. 83-91.

17.Marboutin, E., Bray, Y., Peroux, R., Mauvy, B., Lartiges, A. (2003) Population dynamics in European hare and sustainable harvest rates. J. Appl. Ecol. 40, pp. 580-591.

18. Möller, D. (1975) Zum Altersaufbau der Hasenpopulationen in der DDR, Beitrag zur Jagd. und Wildforschung, IX - Berlin.

19.Meriggi, A., Alieri, R. (1989) Factors affecting Brown hare density in northern Italy. Ethology, Ecology and Evolution, 1, pp. 255-264.

20.Mitchell-Jones, A.J., Amori, G., Bogdanowicz, W., Krystufek, B., Reijnders, P.J.H., Spitzenberger, F., Stubbe, M., Thissen, J.B.M., Vohralik, V. \& Zima, J. (Eds.). (1999). Atlas of European Mammals. Academic Press, London.

21.McLaren, G.W., Hutchings, M.R., Harris, S. (1997) Why are brown hares (Lepus europaeus) rare in pastoral landscapes in Great Britain? Gibier Faune Sauvage, 14, pp. 335-348.

22.Popović, N., Pintur, K., Alegro, A., Slavica, A., Lacković, M. Sertić, D. (2008) Ekološki parametri populacije zeca običnog (Lepus europaeus Pallas, 1778) na području Medjimurja nakon pada brojnosti posljednjih 40 godina, Nat. Croat., 17 (4), pp. 247-257.

23.Panek, M., Kamieniarz, R. (1999) Relationships between density of brown hare Lepus europaeus and landscape structure in Poland in the years 1981-1995. Acta Theriologica, 44, pp. 67-75.

24.Pielowski, Z., Pucek, Z. (1976) Ecology and management of European hare populations. Proceedings of an international symposium held in Poznań on December 23-24, 1974. Państwowe Wydawnictwo Rolnicze i Leśne, Poland.

25.Tapper, S.C., Barnes, R.F.W. (1986) Influence of farming practice on the ecology of the brown hare (Lepus europaeus). Journal of Applied Ecology, 23, pp. 39-52.

26.Tapper, S., Parsons, N. (1984) The changing status of the Brown hare (Lepus capensis L.) in Britain. Mammal Review, 14, pp. 57-70.

27. Slamečka, J. (1991) The influence of ecological arrangements on brown hare population. Proceedings, XXth Congress (eds. S.Csányi, J.Ernhaft), pp. 340-346. International Union of Game Biologists, Gödöllö, Hungary.

28.Slamečka, J., Hell, P., Jurčik, R. (1997) Brown hare in the Westslovak Lowland. Acta Sc. Nat. Brno 31 (3-4), pp. 21-28 and pp.100-103.

29.Erdös, L. (1978) Aprovad gazdalkodás - mezeinyúh, NIMROD FORUM, VII - IX, Budapest 
30.Šelmić, V. (1977) Određivanje realnih odstrelnih kvota zečeva na osnovu ekološke gustine i realnog godišnjeg prirasta populacije (Magistarski rad - Šumarski fakultet Beograd).

31.Šelmić, V. (1984) Proučavanja zakonomernosti dinamike populacije zeca u Vojvodini i njihova primena u planiranju racionalnog korištenja. Disertacija. Šumarski fakultet Beograd, Srbija i Crna Gora.

32.Šelmić, V., Đaković, D., Novkov, M. (1999) Istraživanja realnog prirasta zečijih populacija i mikropopulacija u Vojvodini. Godišnji izveštaj o naučnoistraživačkom radu u organizaciji LS Vojvodine, Novi Sad. pp. 3-9.

33.Suchentrunck, F., Willing, R., Hartl, G.B. (1991) On eye lens weights and other age criteria of the Brown hare (Lepus europaeus Pallas, 1778). Z. Säugetierkunde 56, pp. 365-374.

34.Ristić, A.Z., Ponjiger I., Mijailović, V., Tešić, V., Kovačević, M., Matejević, M., Padejski, P., Marković, V., Lulić, D. (2016): Evaluation of the management of brown hare population in Vojvodina region for the period 1967-2011., Arhiv veterinarske medicine, 9(1), pp. 83 - 92.

35. Ristić, A.Z., Matejević, M. (2010) Losses in hare population during the year, Proceedings of the 45th Croatian \& 5th International Symposium on Agriculture (Eds. Maric, S., Loncaric, Z.), 15-19 February 2010, Opatija, Croatia, pp. 993-997.

Received: 26.07.2019.

Accepted: 24.12.2019.

Ristić Z., Urosevic I.M., Ristić N., Matejević M., Ponjiger I., Kovačević M., Ćirović P. (2019). Planned and rational management of the Brown Hare (Lepus europaeus Pallas,1778) population in Vojvodina region (Serbia) for the past 50 years (1967-2016), Balkan Journal of Wildlife Research, 5 (1), pp. 28-35. 